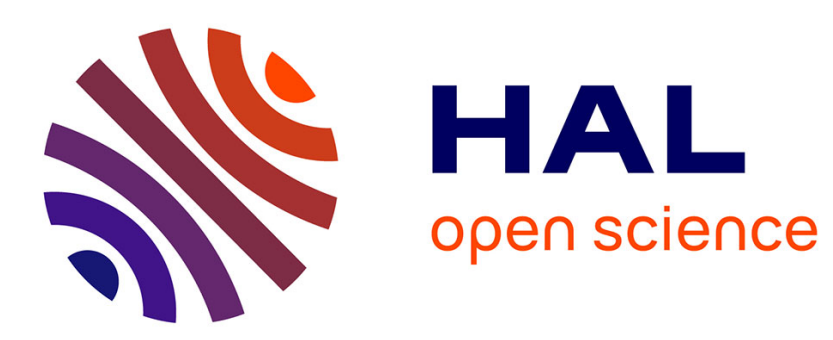

\title{
A case of bone fracture with callus on the right femur of a chicken (Gallus gallus domesticus, L. 1758) from the ancient site of Dharih, Jordan
}

Aurélia Borvon, Claude Guintard, Hervé Monchot

\section{- To cite this version:}

Aurélia Borvon, Claude Guintard, Hervé Monchot. A case of bone fracture with callus on the right femur of a chicken (Gallus gallus domesticus, L. 1758) from the ancient site of Dharih, Jordan. International Journal of Paleopathology, 2018, 22, pp.135-139. 10.1016/j.ijpp.2018.07.004 hal-02336132

\section{HAL Id: hal-02336132 \\ https://hal.parisnanterre.fr/hal-02336132}

Submitted on 28 Oct 2019

HAL is a multi-disciplinary open access archive for the deposit and dissemination of scientific research documents, whether they are published or not. The documents may come from teaching and research institutions in France or abroad, or from public or private research centers.
L'archive ouverte pluridisciplinaire HAL, est destinée au dépôt et à la diffusion de documents scientifiques de niveau recherche, publiés ou non, émanant des établissements d'enseignement et de recherche français ou étrangers, des laboratoires publics ou privés. 


\title{
A case of bone fracture with callus on the right femur of a chicken (Gallus gallus domesticus, L. 1758) from the ancient site of Dharih, Jordan
}

\author{
Aurélia Borvon $^{\mathrm{a}, \mathrm{b}, *}$, Claude Guintard ${ }^{\mathrm{b}, \mathrm{c}}$, Hervé Monchot ${ }^{\mathrm{d}}$ \\ ${ }^{a}$ UMR 7041 Équipe Archéologie Environnementale, 21 allée de l'Université, 92000 Nanterre, France \\ ${ }^{\mathrm{b}}$ Unité d'Anatomie Comparée, Département des Sciences Cliniques, École Nationale Vétérinaire, Agroalimentaire et de l'Alimentation, Nantes-Atlantique ONIRIS, route de \\ Gachet, CS 40706, 44307 Nantes Cedex 03, France \\ ' Groupe d'Études Remodelage osseux et bioMatériaux (GEROM), Université d'Angers, Unité INSERM 922, LHEA/IRIS-IBS, 4 rue Larrey, CHU d'Angers, Angers, France \\ d Labex Resmed, UMR 8167 Orient \& Méditerranée, Sorbonne Universités, 1 place Victor Cousin, 75005 Paris, France
}

Keywords:

Archaeozoology

Fracture

Chicken

Pathology

Medical imaging

Umayyad period

Jordan

\begin{abstract}
A B S T R A C T
Archaeozoology provides bones, which quite regularly present traces of fractures. These fractures are more or less at an advanced level of healing and bear witness to traumas or pathologies. These cases of palaeopathology are not always the subject of publications, which further restricts our knowledge about them. This short note allows the scientific community to be aware of an original case from an archaeological context in Jordan of a fracture on a hen's femur, consolidated by a callus and with displacement of the distal ends. Beyond the "anecdotal" aspect, and without imagining the circumstances in which the fracture occurred, the animal survived.
\end{abstract}

\section{Introduction}

In archaeozoology, paleopathological studies have been carried out for about 40 years (Baker and Brothwell, 1980; Etier-Lafon, 1997; Bartosiewicz and Gál, 2013), and more specifically and recently on birds (Brothwell, 1993; Gál, 2008; Waldron, 2009). Until recently, few cases were published (Guintard, 2005) but works of the Animal Palaeopathology Working Group, an ICAZ (International Council for Archaeozoology) working group, fill this gap (https:// animalpalaeopathologywg.wordpress.com/).

The femur which shows a pathological aspect presented here comes from the ancient sanctuary site of Dharih in Jordan (Fig. 1; Villeneuve and Al-Muheisen, 2000, 2008; Monchot and Béarez, 2016). It comes from a small bone assemblage corresponding probably to a small dump formed during Umayyad occupations of the site i.e. $7^{\text {th }}-8^{\text {th }}$ centuries AD. At that time the temple-church was converted by the new Muslim occupants into their residence, with its annexes as jars storeroom, stable and certainly a barnyard. This bone assemblage contains 121 remains including 57 chicken bones. The remainder is composed of 47 sheep/ goat remains, 8 bones of non-identifiable teleosts and 8 indeterminate fragments.
The chicken bones seem to belong to two individuals, which appear to have been deposited more or less complete (Fig. 2). Although the right and left bones are fairly easily identifiable, it remains difficult to reassign the different parts to their respective original animals. The absence of spurs on the tarsometatarsus indicates the presence of females (West, 1982; Carey, 1982: Bökönyi and Bartosiewicz, 1983; Coy, 1983; Benecke, 1989, 1993; Clavel et al., 1997: Serjeantson, 2009, pp. 47-49: Borvon, 2012, pp. 228-234). The existence of medullary bone necessary for the manufacture of the eggshell - within the diaphysis of a fractured humerus indicates the presence of an individual during the laying period (Rick, 1975; Driver, 1982; Coy, 1983; Serjeantson, 1998, 2009, pp. 49-53; Van Neer et al., 2002; Borvon, 2012, pp. 235-241).

\section{Methods}

The right femur presented in this study was the subject of an osteological description in order to document the bone anomaly present in its diaphysis. At the same time, medical imaging analyses were carried out by the ONIRIS Imaging Department for radiography and scanning. A non-pathological femur from the same archaeological site served as a reference.

\footnotetext{
* Corresponding author at: UMR 7041 Équipe Archéologies Environnementales, 21 allée de l’Université, 92000 Nanterre, France.

E-mail addresses: aureliaborvon@gmail.com (A. Borvon), claude.guintard@oniris-nantes.fr (C. Guintard), herve.monchot@wanadoo.fr (H. Monchot).
} 


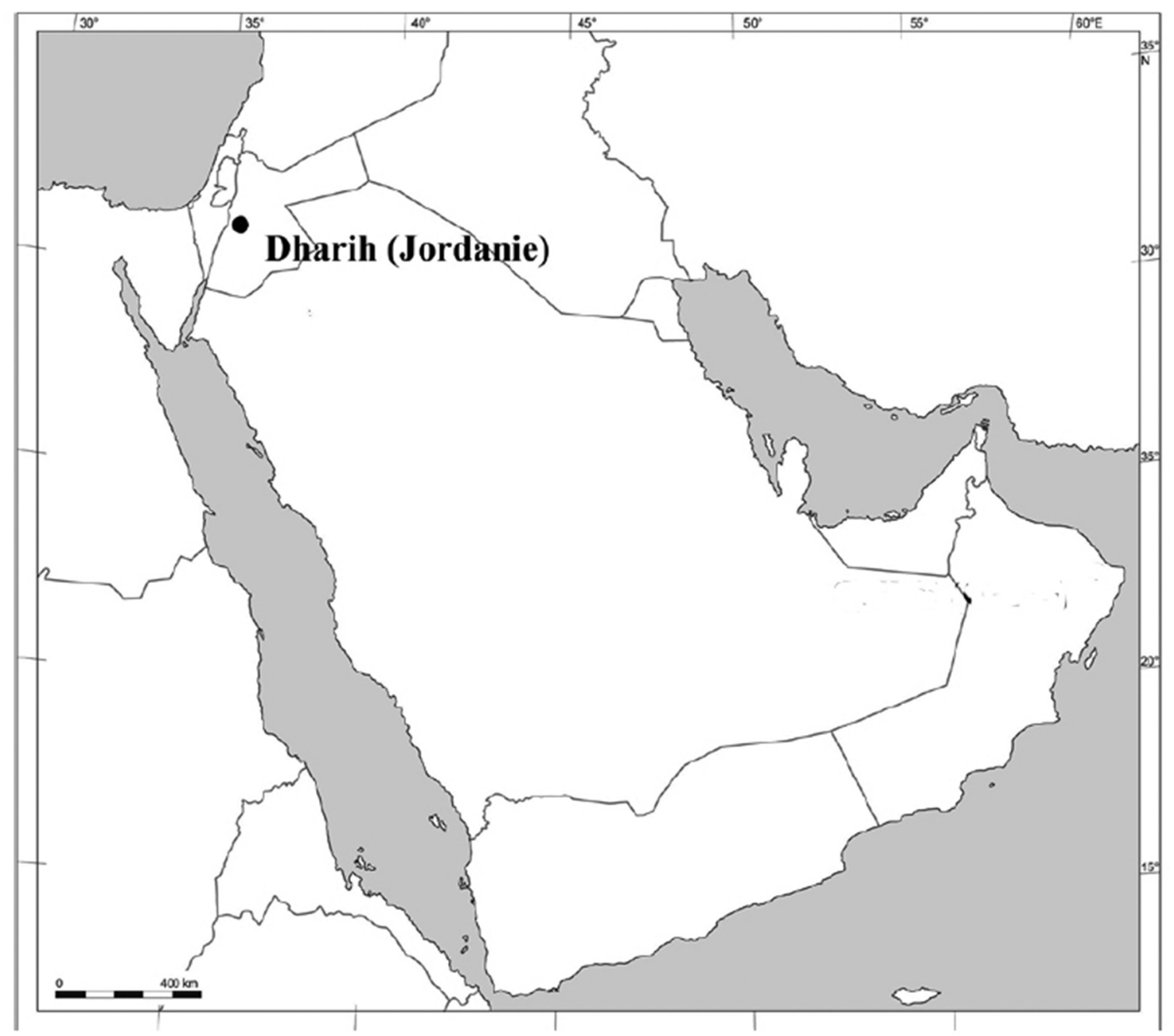

Fig. 1. Location of the archaeological site of Dharih, Jordan (C) DAO H. Monchot and M. Coutureau).

\section{Results}

The femur shows a significant bone callus, on the proximal half of the bone diaphysis (Fig. 3). The two osseous ends of this diaphysis are displaced. This is particularly noticeable on the imaging pictures (Figs. 4 and 5). These deformations are consecutive to a fracture. The Xray picture (Fig. 5) shows that the right femur presents a compact, diaphyseal substance that appears to be thickened. This thickening is due to the presence of medullary bones necessary for the manufacture of the eggshells during the laying period (Whitehead, 2004b). A verification slot confirmed this assumption. In the case of the pathological femur, the abnormal aspect of the bone structure at the diaphysis is not related to the presence of medullary bones. The bone has a trabecular aspect, almost spongy and similar to that observed in the consolidation callus. The modification of the bone microarchitecture is related to the absence of mechanical stresses (Aguado, 2015; Aguado et al., 2017; Libouban, 2015; Whitehead, 2004a; Whitehead and Fleming, 2000) induced by loss of support due to pain and a change in vascularization, the phenomenon of bone healing.

\section{Discussion and conclusion}

The study of bones from archaeological sites provides pathological cases in many assemblages. Rare in general, it is very often fractures more or less consolidated which testify traumatisms (Wood, 1941; Waldron, 2009). A few cases are thus recorded in the rare synthetic articles dedicated to this subject (Brothwell, 1993; Gál, 2008). The description presented here of a fractured femur with bone callus and displacement of the two parts of the bone, is quite similar to the case reported for example in Hungary at the Kiskundorozsma site for the Avar period (Gál, 2008, Fig. 4, p. 44). Despite the fact that the bird femur is a bone largely protected by a significant muscle mass, it is not unusual that this bone is the object of fracture with consolidation (Atherton et al., 2012). The voluminous and powerful muscles (Ghetie et al., 1981) systematically cause a displacement of the osseous parts and concomitantly a reduction of the long length of the bone. The consecutive bone callus consolidates the healing so that the animal resumes normal activity.

In Dharih, all archaeological levels combined, 461 bone remains and 49 eggshell fragments, belonging to dozens of chickens, have been 


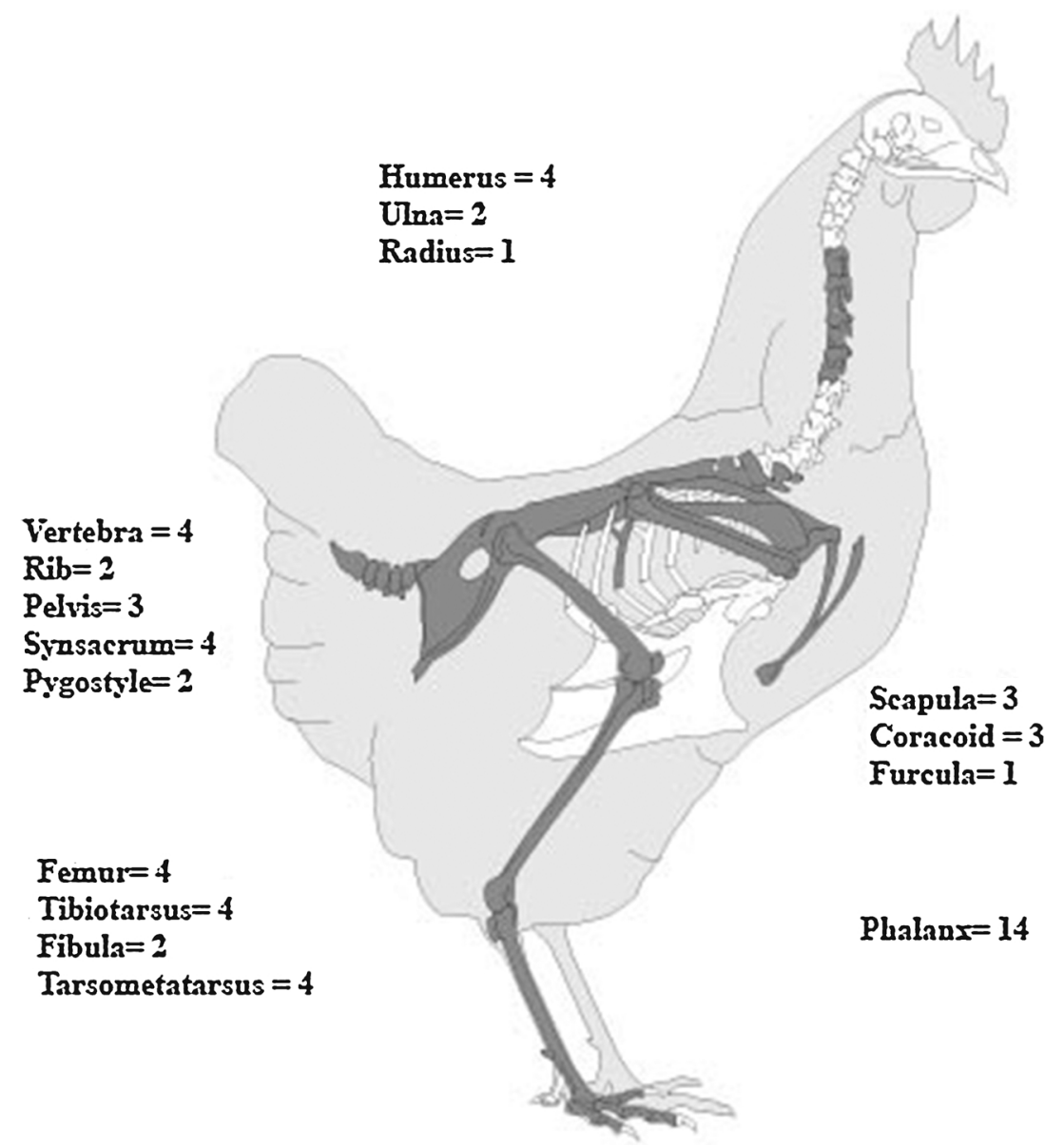

Fig. 2. Chicken skeletal distribution (DH S4G108) in number of identified specimens (C) http://photos.archeozoo.org/; DAO H. Monchot and M. Coutureau).

identified highlighting the importance of poultry in the meat supply of inhabitants. For instance, beside the small dump presented here, 66 chicken remains belonging to 6 individuals were found in the Byzantine-Umayyad filling of a large cistern (Monchot and Béarez, 2016). In Umayyad times, the temple-church area with these abandoned open spaces and its large walls to protect against external predators (i.e. red fox, stone marten) appears a good place to raise chickens. Nevertheless, it is difficult to know if our adult hen came from a free-ranging flock and it would seem that the injuries observed on the latter could be as much the result of human mistreatment as an accident. Its survival and the care that could have been provided while healing took place are certainly related to the fact that she represented a good egg provider.

Although our note produces results that seem modest, the fact remains that archaeozoology would benefit from cases of paleopathology being more systematically brought to the attention of the scientific community.

\section{Acknowledgments}

The authors acknowledge the help of Fr. Villeneuve (Paris ISorbonne University, France) and Z. Al-Muheisen (Yarmouk -Irbid 


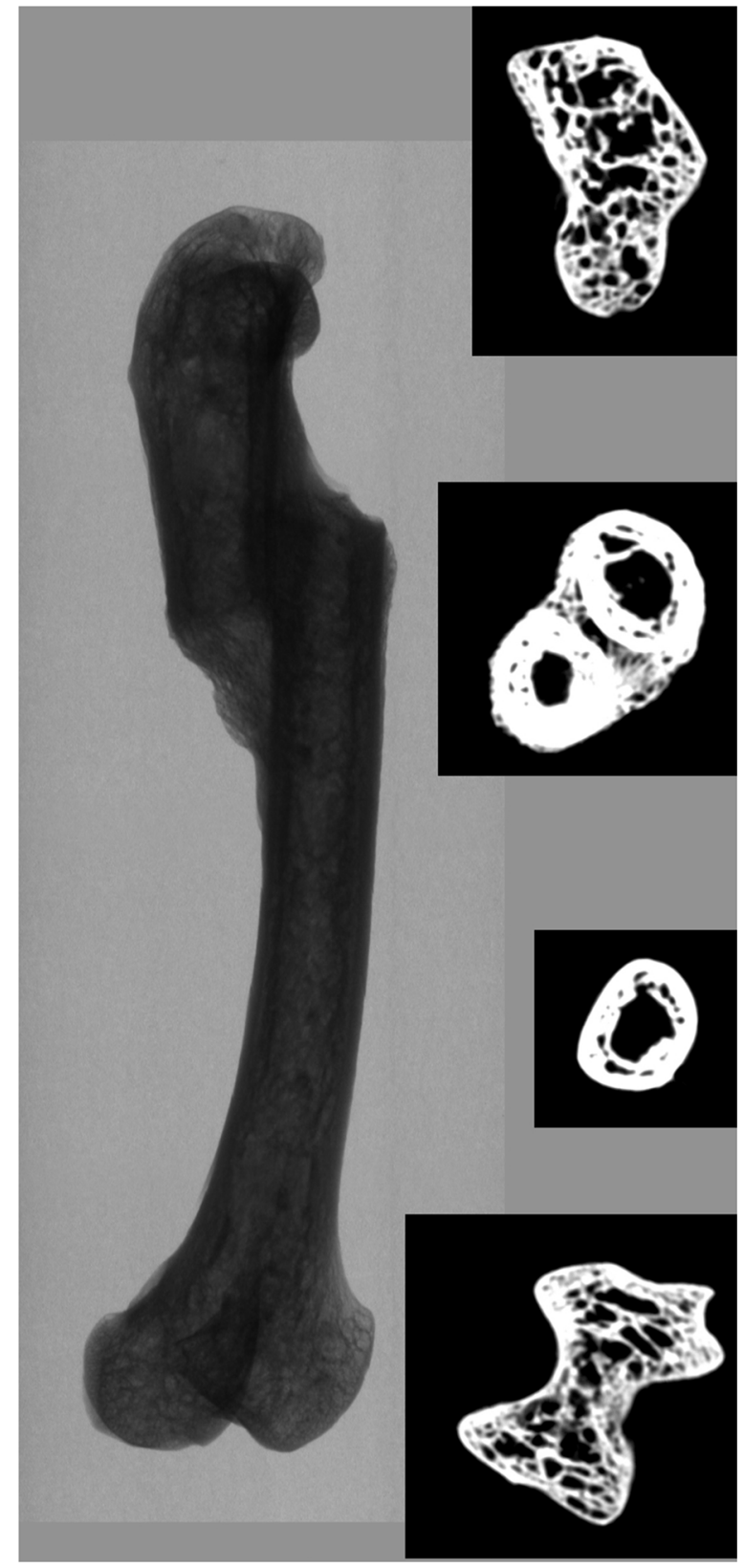

Fig. 3. Photographs of right chicken femurs (DH96 S4G 108) with on the left, bone fracture with consolidation callus, on the right, normal bone; a: caudal views (@ photo $\mathrm{Cl}$. Guintard); b: medial views, scanner 3D reconstruction, surface rendering (ㄷ photo E. Durand).

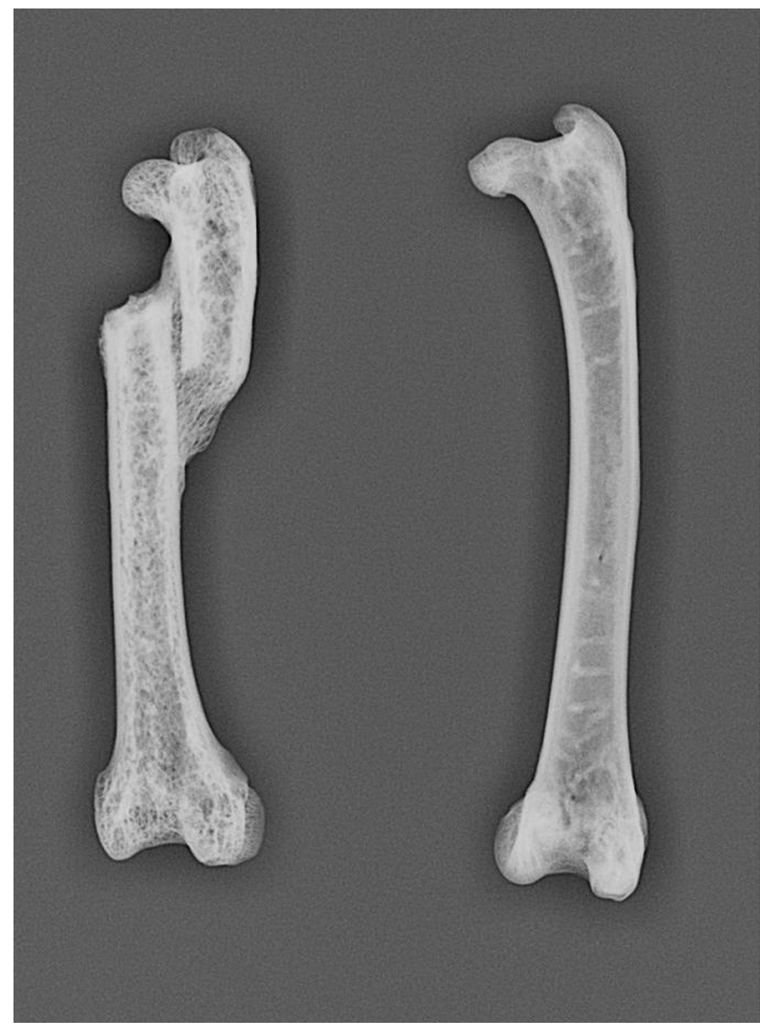

Fig. 4. Scanner picture after 3D reconstruction of the right chicken femur DH96 S4G 108 exhibiting a consolidated fracture, with on the left: 3D reconstruction, and on the right: transversal sections at different levels of the diaphysis (C photo E. Durand and L. Vidal).

University, Jordan) who directed the Dharih archaeological mission and gave us the opportunity to study this bone cluster. Thanks to people who helped in performing scanner and X-ray pictures: Chr. Raphaël (ONIRIS Medical Imagery Unit, Nantes, France), L. Vidal (Nantes University, UFR médecine et technologies médicales, France), and E. Durand (Anato+, Nantes, France) for the 3D reconstruction. Thanks also to Dr. E. Aguado (ONIRIS, Nantes / GEROM Angers, France) and to Dr. H. Libouban (GEROM Angers) who provided recent and pertinent bibliographical references about bone microarchitecture and bone healing. The authors are grateful to Mr. I. Nicholson, for his precious help in the proofreading of this manuscript. 


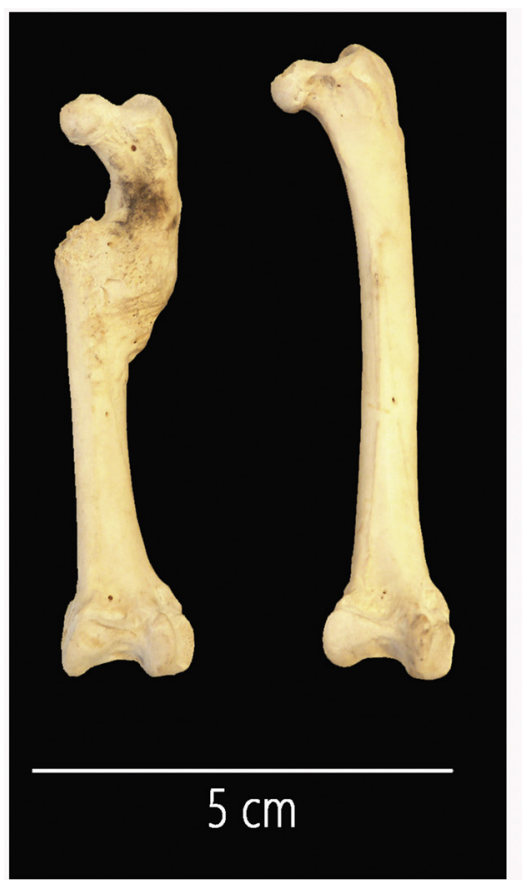

a

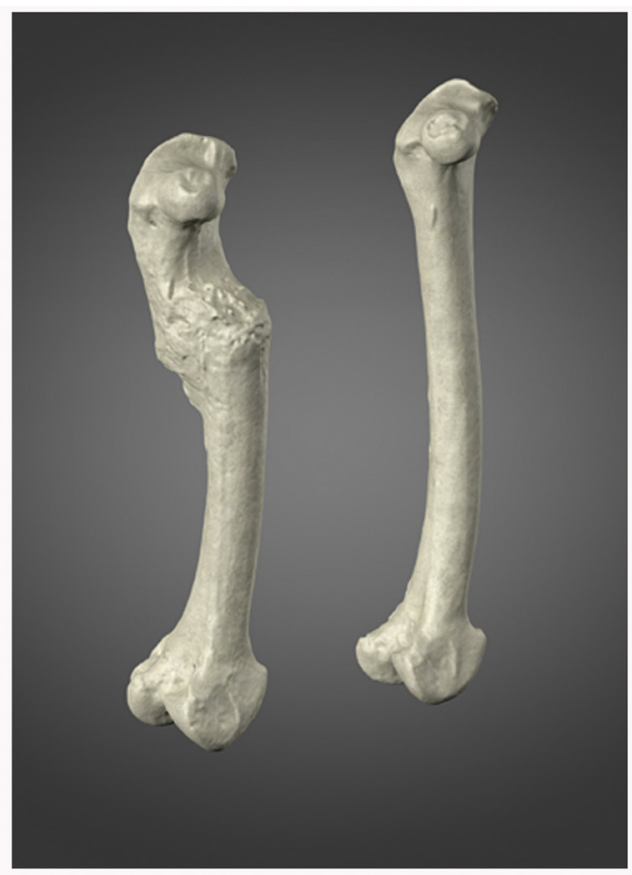

b

Fig. 5. X-ray picture of right chicken femurs DH96 S4G 108, with on the left: fractured bone with consolidated callus; on the right: normal femur, cranio- caudal incidence (C Service Imagerie ONIRIS).

\section{References}

Aguado, E., 2015. Modèles animaux et biomatériaux. In: Audran, M., Guillaume, B., Chappard, D. (Eds.), Tissu osseux et biomatériaux en chirurgie dentaire. QI, Paris, pp. 307-322.

Aguado, E., Mabilleau, G., Goyenvalle, E., Chappard, D., 2017. Hypodynamia alters bone quality and trabecular microarchitecture. Calcif. Tissue Int. https://doi.org/10.1007/ s00223-017-0235-x.

Atherton, S., Brothwell, D., David, R., McKnight, L., 2012. A healed femoral fracture of Threskiornis aethiopicus (Sacred Ibis) from the animal cemetery at Abydos, Egypt. Int. J. Paleopathol. 2, 45-47.

Baker, J., Brothwell, D., 1980. Animal Diseases in Archaeology. Academic Press, London. Bartosiewicz, L., Gál, E., 2013. Shuffling Nags, Lame Ducks: The Archaeology of Animal Disease. Oxbow Book, Oxford.

Benecke, N., 1989. Zum Geschlechtsdimorphismus am Skelett mittelalterlicher Haushühner (Gallus gallus f. domestica). Zool. Abhandlungen Staat. Museum für Tierkunde Dresden 45, 23-33.

Benecke, N., 1993. On the utilization of the domestic fowl in Central Europe from the iron age up to the Middle Ages. Archaeofauna 2, 21-31.

Bökönyi, S., Bartosiewicz, L., 1983. Testing the utility of quantitative methods in sex determination of hen (Gallus domesticus L.) bones. Zool. Anzeiger 210, 204-212.

Borvon, A., 2012. Acquisition des ressources animales, alimentation carnée et distinction sociale en Anjou de la fin du X $\mathrm{X}^{\mathrm{e}}$ au début du XII ${ }^{\mathrm{e}}$ siècle. Étude archéozoologique du site de Montsoreau (Maine-et-Loire). Thèse de Doctorat, Université Paris 1 PanthéonSorbonne. https://hal.archives-ouvertes.fr/tel-00669956.

Brothwell, D., 1993. Avian osteopathology and its evaluation. Archaeofauna 2, 33-43.

Carey, G., 1982. Ageing and sexing domestic bird bones from some late medieval deposits at Baynard's castle, city of London. In: Wilson, B., Grigson, C., Payne, S. (Eds.), Ageing and Sexing Animal Bones from Archaeological Sites. BAR British Series, Oxford, pp. 163-268.

Clavel, B., Lepetz, S., Marinval-Vigne, M.-C., Yvinec, J.-H., 1997. Évolution de la taille et de la morphologie du coq au cours des périodes historiques en France du Nord. Ethnozootechnie 58, 3-12

Coy, J., 1983. Birds as food in prehistoric and historic Wessex. In: Grigson, C., CluttonBrock, J. (Eds.), Animals and Archaeology. 2: Shell Middens, Fishes and Birds. BAR Int. Series, Oxford, pp. 181-195.

Driver, J.C. 1982. Medullary bone as an indicator of sex in bird remains from archaeological sites. In: Wilson, B., Grigson, C., Payne, S. (Eds.), Ageing and Sexing Animal Bones from Archaeological Sites. BAR British Series, Oxford, pp. 251-254.

Etier-Lafon, V., 1997. Présentation de la paléopathologie animale. Étude de cas. Thèse de Doctorat Vétérinaire. École Nationale Vétérinaire de Toulouse.
Gál, E., 2008. Bone evidence of pathological lesions in domestic hen (Gallus domesticus Linnaeus, 1758). Vet. Ir. Zoot. 41 (63), 42-48.

Ghetie, V., Chitescu, St., Cotofan, V., Hillebrand, A., 1981. Atlas de anatomía de las aves domesticas. Paraninfo, Madrid.

Guintard, C., 2005. L'histoire de la médecine vétérinaire : apport des sources écrites (Moyen-âge et époque moderne) et réflexions sur l'intérêt et les limites de l'archézoologie pour l'étude de la paléopathologie animale. In: Mousnier, M. (Ed.), Les animaux malades en Europe occidentale $\left(\mathrm{VI}^{\mathrm{e}}\right.$-XIX ${ }^{\mathrm{e}}$ siècle), actes des XXV $\mathrm{V}^{\mathrm{es}}$ Journées Internationales d'Histoire de l'Abbaye de Flaran, septembre 2003. Presses Universitaires du Mirail, Toulouse, pp. 125-152.

Libouban, H., 2015. La réparation osseuse après fracture et au contact des implants, consolidation osseuse périfracturaire. In: Audran, M., Guillaume, B., Chappard, D. (Eds.), Tissu osseux et biomatériaux en chirurgie dentaire. QI, Paris, pp. 186-190.

Monchot, H., Béarez, P., 2016. Des ossements dans les citernes. Les exemples de Dharih (Jordanie) et de Oalhat (Oman) 93. pp. 339-352 Syria.

Rick, A.M., 1975. Bird medullary bone: a seasonal dating technique for faunal analysts. Can. Archaeol. Assoc. 7, 183-190.

Serjeantson, D., 1998. Birds: a seasonal resource. Environ. Archaeol. 3, 23-33.

Serjeantson, D., 2009. Birds. Cambridge University Press, Cambridge.

Van Neer, W., Noyen, K., De Cupere, B., Beuls, I., 2002. On the use of endosteal layers and medullary bone from domestic fowl in archaeological studies. J. Archaeol. Sci. 29, $123-134$.

Villeneuve, F., Al-Muheisen, Z., 2000. Nouvelles Recherches À Khirbet Edh-Dharih (Jordanie du Sud, 1996-1999). C. R. Acad. inscript. Belles-Lettres 144, 1525-1563.

Villeneuve, F., Al-Muheisen, Z., 2008. Le sanctuaire nabatéo-romain de Dharih (Jordanie) : nouvelles découvertes, 2001-2008. C. R. Acad. inscript. Belles-Lettres 152, 1498-1520.

Waldron, T., 2009. Palaeopathology. In: Serjeantson, D. (Ed.), Birds. Cambridge University Press, Oxford, pp. 55-61.

West, B., 1982. Spur development: recognizing caponized fowl in archaeological material. In: Wilson, B., Grigson, C., Payne, S. (Eds.), Ageing and Sexing Animal Bones from Archaeological Sites. BAR British Series, Oxford, pp. 255-261.

Whitehead, C.C., 2004a. Skeletal disorders in laying hens: the problem of osteoporosis and bone fractures. In: Perry, G.C. (Ed.), Welfare of the Laying Hen, Poultry Science Symposium Series, pp. 259-278 CABI, Bristol.

Whitehead, C.C., 2004b. Overview of bone biology in the egg-laying hen. Poult. Sci. 83, 193-199.

Whitehead, C.C., Fleming, R.H., 2000. Osteoporosis in cage layers. Poult. Sci. 79, 1033-1041.

Wood, H.B., 1941. Fractures among birds. Bird-Banding 12, 68-72. 